\title{
The roots of Norwegian epidemiology - Norwegian epidemiology in the 19th century
}

\author{
Lorentz M. Irgens \\ Department of Global Public Health and Primary Health Care, University of Bergen \\ E-mail: lorentz.irgens@uib.no
}

This is an open access article distributed under the Creative Commons Attribution Licence, which permits unrestricted use, distribution, and reproduction in any medium, provided the original work is properly cited.

\section{INTRODUCTION}

When we try to identify the historical roots of epidemiology, a clarification of what we are looking for is not trivial. The concept of epidemiology in the $19^{\text {th }}$ century is far from obvious. In general, epidemiology is motivated by an urge to hinder disease from occurring with needs of action in terms of preventive medicine. Essential is a search for risk factors; preferably modifiable risk factors that would be strategic in the fight against disease or in the prevention of disease. In this perspective, Norwegian epidemiology is rooted in the $19^{\text {th }}$ century.

Epidemiology in the $19^{\text {th }}$ century seems to relate to two different contexts. In part, the development was related to a gradually evolving concern for the wellbeing of a deprived population which early in the century initiated a broad so called reform movement. In part epidemiology was rooted in more acute and thereby more challenging incidents e.g. epidemics with an urgent need to search for the cause of a specific disease in order to combat and prevent an important specific public health problem.

\section{A REFORM MOVEMENT}

The first context was a consequence of Napoleon's (1769-1821) reorganization of the country after the French revolution. The recruitment to the medical profession was broadened, the profession's responsibility for the community developed and many medical misbeliefs were eliminated. The success of this movement from a medical point of view was due to the association between poverty and poor health. The era of this reform movement in France came to an end towards the middle of the $19^{\text {th }}$ century, possibly due to the lack of public health data; France did not develop a vital statistics system $(1,2)$. However, in Britain the movement flourished due the presence of such a system, attributable to William Farr (1807-83), a physician trained on the continent. In the 1830s, Farr directed this reform movement into a medical statistical movement (1). The members of this movement considered the use of social facts in terms of data as a valuable weapon in the fight against poverty and thereby disease. The barrister Edwin Chadwick (1800-90) provided a legal basis for the movement, i.a. in terms of the Public Health Act of 1848.
This reform movement had its counterparts in Norway. Numerous accounts from physicians relate to the poor living conditions of the population and the ensuing health problems. In particular, the district health officers, members of a national public health network established in 1836, expressed great concern. However, perhaps the most outstanding representative of a reform movement in Norway was the theologian Eilert Sundt (1817-75) (3). After graduating in 1846, Sundt worked as a teacher in a prison where he took a particular interest in the romani prisoners. Financed by the Government, he studied this ethnic group and published in 1850 his first thesis, "An Account on Tramps and Vagabonds in Norway". At the time, this group was considered a great social problem in Norway and Sundt argued for integration of the group into the general community.

Eventually, Sundt came to envisage the challenge of the romani group as a part of a general poverty problem which he referred to as pauperism. Sundt rectified a number of misbeliefs. An alarming high birth rate in the 1840 s was attributed by the general public to sexual irresponsibility by the youth and as one among many symptoms of pauperism. However, based on vital

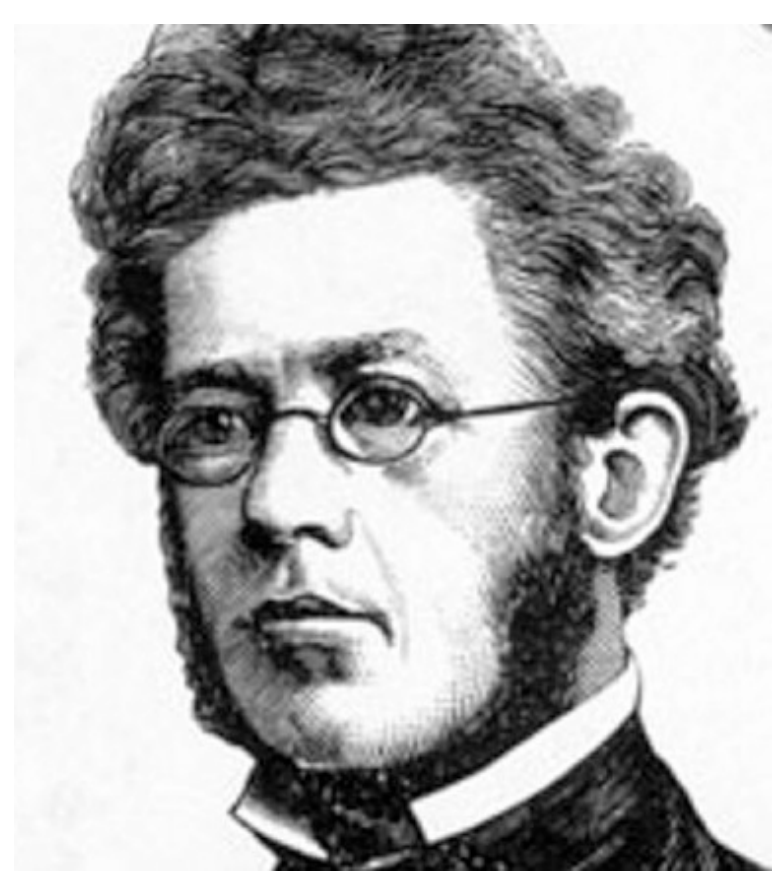

Eilert Sundt (1817-1875). 
statistics, Sundt showed in an elegant analysis that the high birth rate was a consequence of a large previous generation; it was not due to sexual irresponsibility. These waves in birth rates have been referred to as "Eilert Sundt's Law" (3). The study, "On marriage in Norway" from 1855, represents the first serious effort in Norway to establish analytical demographic research based on vital statistics.

Furthermore, the same year Sundt published "On mortality in Norway" also based on vital statistics (4). In a remarkable chapter, he dealt with sudden infant death syndrome (SIDS) or what he called "to death lain children". He reported an incidence during 183745 of 1.2 per 1000 livebirths, remarkably similar to the incidence in Norway before the SIDS epidemic that started in the 1970s (5). He also reported that children born out of wedlock had a 2.2 fold higher risk which he attributed to the "lacking ability of these unhappy mothers to care for their children. While the happy wife as a rule has her child in a cot near her bed, the unmarried maid has to lay her child in her own bed" (4). In the $1980 \mathrm{~s}$, the infants of unmarried mothers had a 1.7 fold excess risk of SIDS (6) and the risk of bedsharing was convincingly established (7).

These examples show that Sundt was an eminent representative in Norway of the European reform movement. They also demonstrate the importance of exploiting vital statistics for public health purposes. Later, Sundt published i.a. on sexual habits (1857), rural building customs (1862) and cleanliness (1869). His study on sobriety from 1859 is methodologically most remarkable, based on reports from teachers all over the country on drinking habits of 180,000 males.

Sundt has been called the father of Norwegian sociology (3), an honour easily defended and fully deserved. However, to which extent his merits represent epidemiology is more questionable. Apart from his conviction that pauperism is related to health, he demonstrated no search for causes of specific diseases. From an epidemiological point of view, he was more concerned with demographic exposures than with medical outcomes. His numerous and most impressive studies did not result in the implementation of concrete preventive measures. It has been pointed out that his suggestions to resolve the challenges he had identified were few and only rarely beyond the obvious or trivial (3). This may be the reason why a narrow minded Norwegian Parliament discontinued his financial support. In 1869 he was offered a vicarage as compensation, which he accepted.

\section{SEARCH FOR SPECIFIC CAUSES OF SPECIFIC DISEASES}

Poverty had been prevalent since time immemorial. However, the first half of the $19^{\text {th }}$ century saw far more imminent threats to the community, threats that came to spur the development of epidemiology; our second context. The threats related to infectious diseases and the efforts came to follow two different strategies; the search for epidemiological mechanisms and the search for etiological agents. These two strategies may be illustrated by Ignaz Semmelweis' (1818-65) work with puerperal fever. In Vienna, the mortality of this complication after delivery increased to a dramatic and unacceptable 114 deaths per 1000 births (8) calling for immediate action. By meticulous observation and registration of data, Semmelweis disentangled the epidemiological mechanism and installed measures to successfully combat the disease without any efforts to identify the etiological agent which would have represented the second strategy.

Puerperal fever was a considerable problem in some maternity hospitals. However, in the first half of the $19^{\text {th }}$ century, Europe came to face a far more threatening challenge; viz. cholera. In London, John Snow (1813-58) conducted his famous studies in accordance with the strategy of disentangling epidemiological mechanisms, demonstrating the great benefits of a method often referred to in a derogatory way as black box epidemiology. During the first half of the $19^{\text {th }}$ century, Norway as well as the rest of Europe was in a state of confusion with respect to the epidemiology of cholera. Still the disease made a great impact on the development of epidemiology.

First of all it put on the agenda the concept of searching for specific causes of specific diseases. With respect to cholera two main different opinions seemed to occur; that cholera was an infectious disease dependent on contact between persons or alternatively that cholera was caused by miasma. Today, the latter hypothesis seems rather incomprehensible, the striking epidemic pattern of the disease taken into consideration. However, with a large number of seemingly healthy carriers, and with drinking water as a main source of infection, a person to person mechanism might seem unlikely. Furthermore, a high prevalence at any time of gastroenteritis due to other causes and with symptoms often difficult to discern from those of cholera, the epidemic pattern of cholera might have been difficult to ascertain, even though a system for producing morbidity and mortality statistics was established just after 1800. All doctors were obliged to forward to the central health authorities annual reports with numbers of patients with specified diagnoses. At the same time notification of epidemic cases was introduced. These regulations were motivated by a wish to combat infectious diseases (9).

Even with this epidemiological confusion, cholera was, also in Norway, subject to regulations of isolation and quarantine (10). It has been suggested that adequate regulations prevented the first European epidemic in 1829 from hitting Norway. The first epidemic in Norway occurred in 1832 in Drammen. Yet, in 1833, shipping and trade interests argued for lifting the regulations. Consequently, they were no longer thoroughly enforced, leaving the country open to cholera (11). Total number of cholera deaths in Norway 1832- 
72 has been estimated at $6,000(10)$.

In spite of a long lasting confusion, an institution most important from a public health point of view was the result of the cholera epidemics in Norway, viz. the local Boards of Health, comprising lay and learned members of the local community. The first of these boards was established in 1805 related to the quarantine administration (10). From the 1830s onwards, ad hoc local Boards of Health were set up in every health district hit by an epidemic. In 1854, permanent boards were established in all districts where leprosy was present (12) and in 1860 local Boards of Health were established, in accordance with the Health Act of the same year, in all municipalities in the country.

The fight against cholera became a public concern to the extent that it was reflected in Henrik Ibsen's (1832-1906) play "An Enemy of the People" of 1882. A Norwegian town is threatened by an epidemic caused by microscopic "infectious animals", and the hero, the whistleblowing physician, turns out to be the enemy.

From a scientific point of view, the cholera epidemics woke the interest to study the causes of other diseases. Particularly the concept of "contagium vivum" was hotly debated over a long time. Beyond the debates were epidemiological field studies conducted by Christian H. Homan (1826-89) and Christian H. Hartwig (1824-92) on dysentery (13) in 1859 and on typhoid fever (14) in 1865 . Both were district health officers previously working as cholera doctors and with scientific contacts on the Continent. They concluded that the epidemiological mechanism was that of an infection due to person to person contact. They were also interested in the etiological agent and inferred, from their data, the existence of infectious agents responsible for the propagation of these diseases $(13,14)$.

The etiological agent was the direct interest of Emanuel F. G. Winge (1827-97) and Hjalmar Heiberg (1837-97) who in 1869 demonstrated "rosary-like threads" on heart valves in patients who died of sepsis. The "threads" were considered to be pathogenic microorganisms and were later identified as streptococci (15).

\section{LEPROSY: A CHALLENGE TO PUBLIC HEALTH}

The scattered efforts in research accounted for above are barely visible on the international stage of epidemiology. However, in the field of leprosy, Norway approached worldwide excellence in terms of achievements related to the reform movement, research into epidemiological mechanisms and etiological agents as well as successes with respect to control programme and preventive measures.

It all started on a modest scale in Bergen in the 1810s (16). Opposite to the rest of Northern Europe, leprosy continued to be prevalent in Norway until the middle of the $19^{\text {th }}$ century. However representing no novelty and being non-epidemic, the disease attracted limited interest among lay as well as learned. In an article to the Swedish Medical Journal in 1816, the vicar of St George's leprosarium in Bergen tried, almost in vain, to call attention to the suffering of the 150 inmates of the hospital which was characterized as a graveyard for the living (16).

Eventually it became clear that leprosy was a challenge far beyond the inmates of St George's, however its dimensions were far from clear. Thus a physician, Jens J. Hjort (1798-1873) was engaged by the health authorities, in the spirit of the reform movement, to travel about the various districts of the country and report on the extent and gravity of the problem and whether anything could be done to improve the condition of the patients. In his report, Hjort was unable to quantify the health problem with any degree of certainty, but held the opinion that there was a great need for hospital beds both for treatment and care (16).

Next, to obtain more definite information about the magnitude of the problem, the authorities in 1836 conducted a census of all leprosy patients in the country effectuated by the parish vicars. Altogether 659 patients were ascertained or 5 per 10,000. However, the system of registration was obviously inaccurate, and it was assumed that the real number was far higher (16).

In the further development, a number of factors played a part. The medical actors had their education at the University of Christiania, however, many of them went abroad to have post graduate training on the Continent or in Britain. They were well aware of scientific medical progress as well as political trends including the various reform movements. Many of them had a remarkable responsibility towards their community at large. In addition, Norwegian nationalism was boosted after a short period of independence in 1814 followed by a union with Sweden, a nationalism with democratic roots clearly visible in the Constitution enacted the same year by an ad hoc elected parliament (17). This democratic nationalism took great interest in what was considered typical Norwegian elements, and such elements were particularly found among farmers and fishermen in remote and rural areas; areas in which leprosy raged. Thus leprosy came to represent a political humanitarian challenge and, in this perspective, a national disgrace.

Thus, during the first half of the $19^{\text {th }}$ century in Norway, the conditions necessary to identify and mobilize against an important public health problem were at hand. The second half of the century came to see the resolution of the challenges. However, important efforts were made already in the 1830 s and the 1840 s (16). On the political stage, the initiative was taken by a governmental medical commission, to build four leprosy hospitals in areas where the disease was prevalent, but with no immediate success; at first no plans were realized due to lack of finances. However, the political pressure increased. In a new patient census of 1845 the prevalence amounted to 8 patients per 10,000 , which still was considered to be the tip of an iceberg. 
In the medical field an important step was taken when Daniel C. Danielssen (1815-94) in 1839 was appointed physician at St George's Hospital in Bergen (18). The proposition, to build a number of leprosy hospitals, would represent a heavy financial burden to a nation, at that time one of the poorest in Europe. Thus, the health authorities were urged to act on the basis of solid evidence. Consequently, Danielssen was requested by the governmental commission to continue the studies he had already started on the clinical and pathological aspects of leprosy. At the same time Carl W. Boeck (1805-75), a medical officer at a large silver mine, was awarded a scholarship to study the occurrence of the disease in other European countries.

The first results of their work were reported in 1842 to be followed by a monograph published by the Government both in Norwegian (1847) and in French (1848); "Traite de la Spedalskhed ou Elephathiasis des Grecs" (19), later awarded the prestigious Prix Monthyon.

The monograph has two main sections; first a critical review of former literature on leprosy and secondly an account of the authors' results with documentation and discussion. Among the results, the clinical observations are most significant. Most important is the identification of leprosy as a clinical entity with criteria for diagnosing the disease including its polar forms and criteria for separating leprosy from a number of differential diagnoses. Also prognosis was accounted for; mean survival after onset was estimated at 9.5 and 18.5 years for the two polar forms respectively.

Also results of epidemiological research were presented in terms of comprehensive family pedigrees. On this basis, leprosy was considered to be caused by several factors. Usually, leprosy was a hereditary disease, but one-eighth of the cases were due to so called random factors such as hard toil, poor diet and bad living conditions. The authors argued strongly against an etiology of infection. Discordance among spouses and the fact that numerous persons had lived together with leprosy patients in St George's Hospital without getting the disease ruled out such an etiology. Detailed information on the geographic occurrence of leprosy was published based on the 1845 census with a prevalence of more than 100 per 10,000 of the population in the most affected districts.

The book came to have fundamental influence on subsequent leprosy research also internationally, and the two scientists became recognized authorities; Rudolf Virchow (1821-1902) stated in 1864 that compared with this monograph, earlier works were of little scientific interest (20). Still, some critical voices were heard at least in the discussion of etiology; in an interesting review of the book, a colleague dryly commented that with respect to contagiousness, his doubts had not been eradicated (21).

Politically, this research paved the way for a new hospital in Bergen opened in 1849; the Lungegaards-

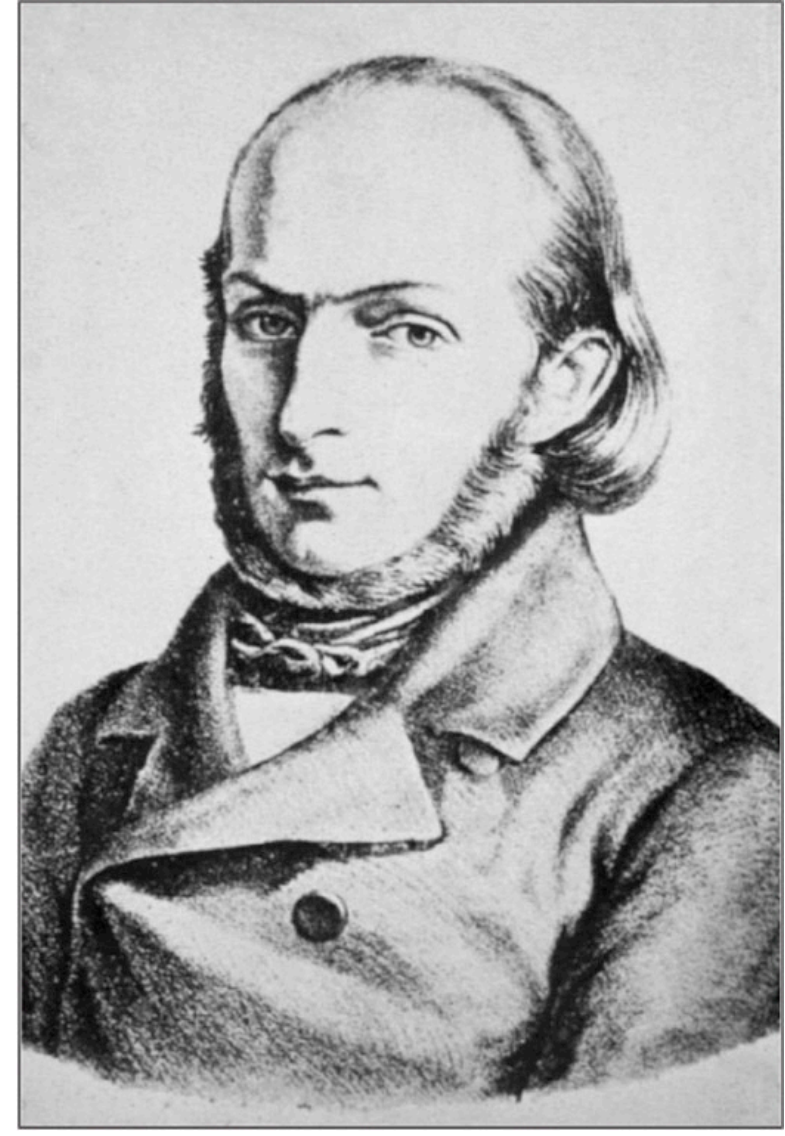

Daniel C. Danielssen (1815-1894).

hospitalet with Danielssen as its first head. The specified intention was to develop a cure for leprosy, not only to care for the patients. Thus, this hospital came to be the only research hospital in the country ever established for any disease. Paradoxically, its establishment was the result of a compromise, in part due to the lack of money to build the four hospitals for care. In part the compromise was due to lack of consensus with respect to etiology. The medical commission, arguing that leprosy was a hereditary disease, wanted to isolate the patients in these hospitals to inhibit their reproduction. This policy was strongly opposed in Parliament and also by medical colleagues (21).

\section{The National LeProsy Registry OF NORWAY}

In spite of significant achievements mainly in clinical research and important political commitment by the end of the first half of the $19^{\text {th }}$ century, confusion and irresolution remained with respect to leprosy. The true magnitude of the public health problem was still unclear, but its outlines were frightening. The prevalence seemed to be increasing; a third census conducted in 1852 showed a prevalence of 11 per 10,000 (16). New cases reported from the neighbourhood of the capital might have been particularly scaring. Furthermore, nothing had been done to establish care for the many sufferers. Finally, no control measures had been 


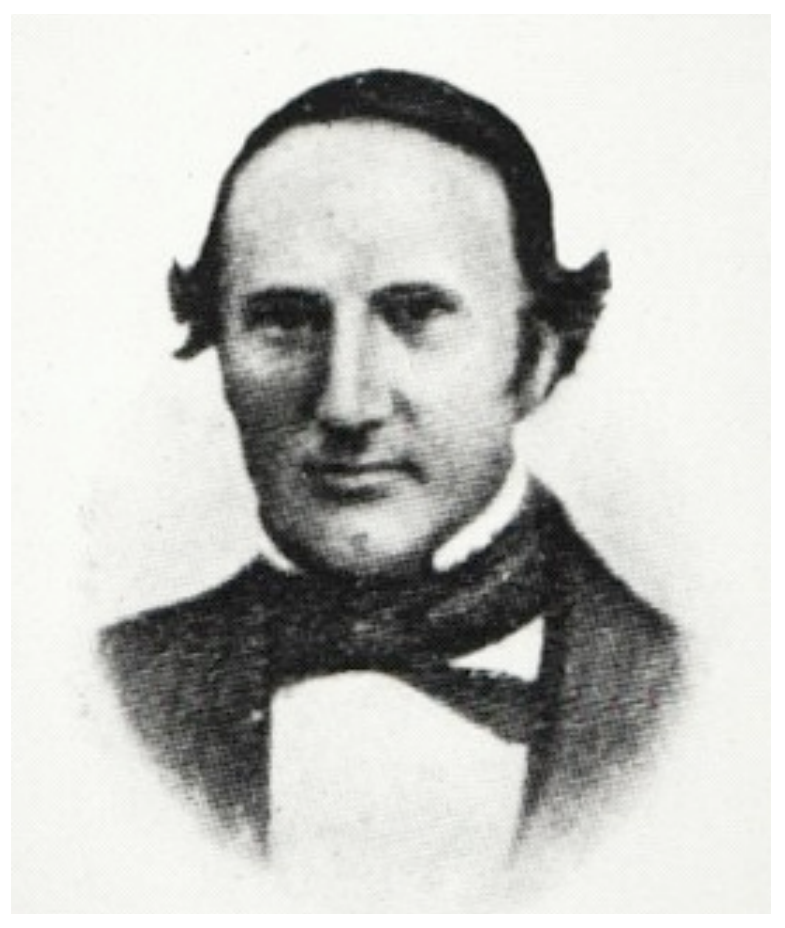

Ove Guldberg Høegh (1814-1863).

enforced. It was generally held that effective control measures had to be based on firm evidence with respect to etiology (21). However, such evidence was lacking.

During the period 1850-70, the leprosy question came to attract paramount attention in medical circles. Thus, in 1857 it was the subject of a protracted discussion in the capital's Medical Society (22); etiology and control measures were the two main topics. In addition to a hereditary mechanism, also miasma were advocated (22) and Hjort maintained that leprosy was a degenerative condition with various causal factors, most often being the result of harsh physical conditions of life. A few spokesmen claimed that leprosy was an infectious disease $(21,22)$.

In an attempt to mobilize against the disease, the health authorities established the post of a Chief Medical Officer for Leprosy, and Ove Guldberg Høegh (1814-63) was appointed in 1854. Høegh, at that time a District Health Officer in Senja, was a Member of Parliament representing Finnmark county. Høegh realized that practical control measures, irrespective of grounds, would have to be based on current data on each patient. There was a need for the establishment of a central patient registry (23). A registry would make it possible to assemble all current data in a way that would indicate where control measures and care were most in need, and it would permit the evaluation of time trends and a control programme. Høegh also appreciated that a registry would provide a basis for co-operation between practical public health work and research, particularly in terms of epidemiological studies on the etiology of the disease.

The National Leprosy Registry of Norway was established by a Royal Decree of 30 July 1856 (12). Local registration was entrusted the District Health Officer assisted by the parish vicars and the members of the local Board of Health. New cases of leprosy were notified annually to the central registry. At the same time, all new data on a patient already registered were notified; e.g. hospitalization, migration to another health district, cure and death. Local registration was conscientiously supervised by the Chief Medical Officer for Leprosy who visited the districts, seeing most of the patients and assisting the District Health Officer with diagnostic problems.

Høegh, in his Annual Report of 1856 (23), attached ambitious aims to the Leprosy Registry in terms of clarifying the etiology of the disease. He concluded that clinical and pathological studies alone would not be sufficient. Epidemiological studies were necessary, and those conducted until then had been too small. Collection of detailed data on all patients in the country would be needed; indeed a precursor of megaepidemiology. The National Leprosy Registry of Norway came to represent the first national medical registry for any disease in history. Prophetically, Høegh announced that it was by the processing of all these data that one should learn the causes of leprosy. And this came true. Even though he died before the scientific breakthrough, and the work had to be completed by someone else, his achievements with respect to the establishment and initial running of the registry and his grand and clairvoyant programme conceived during a period of general scientific confusion, make Ove Guldberg Høegh the father of Norwegian epidemiology.

Reliable information from the Leprosy Registry indicated that in 1855, Norway had around 2,500 leprosy patients or 16.7 per 10,000 substantiating the unmet need for care (24). During the ensuing years, the Parliament voted money for building another three hospitals in Bergen, Molde and Trondheim housing altogether 680 patients. Including the 250 beds in $\mathrm{St}$ George's and Lungegaardshospitalet, Norway in 1864 had 900 beds for leprosy patients or a bed for $36 \%$ of all patients in the country; a remarkably high percentage. As a consensus with respect to etiology was still lacking, this ambitious programme was motivated in the Parliament on direct humanitarian grounds, viz. in terms of need for care.

\section{CLARIFICATION OF THE ETIOLOGY OF LEPROSY}

Gradually, Bergen developed into a centre for leprosy research of international reputation (20) and came to attract young physicians eager to address the challenges represented by leprosy. Among them was Gerhard Henrik Armauer Hansen (1841-1912) (25). Born in Bergen, Hansen graduated from the University in Christiania in 1866. After a year as an intern at the University Hospital and a few months as a doctor for fishermen in the Lofoten region in the north, Hansen, 


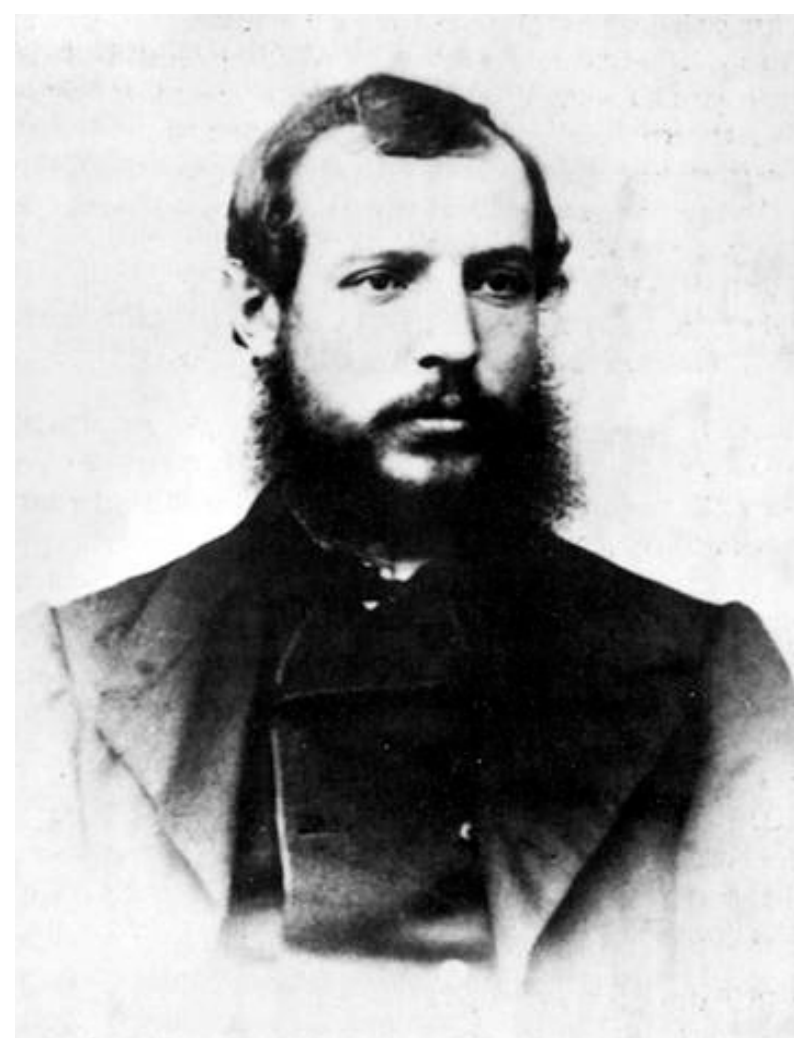

Gerhard Henrik Armauer Hansen (1841-1912).

in 1868, got a post as a physician at the Lungegaardshospital in Bergen with Danielssen as his superior and mentor. Already at an early stage, Hansen was of the opinion that leprosy was an infectious disease, but in spite of growing differences of opinion with respect to etiology, Danielssen provided Hansen with good working conditions. Apparently, the disagreement between them was purely academic; in 1873 Hansen married Danielssen's daughter, Stephanie Marie.

Hansen's opinion that leprosy was infectious might seem surprising. In the hot national debate, most discussants including his mentor argued that leprosy was a hereditary disease. To clarify the etiology of leprosy was a challenge also abroad. In 1867, The Royal College of Physicians issued a report on the basis of replies to 17 questions relevant to the cause of leprosy obtained from 250 physicians in all British colonies. However, the answers were most contradictory (26). First to present results relating to etiology based on a large number of observations was Høegh. Already in 1857, after having processed the data from the first year of running the Leprosy Registry, he held that the results gave support to the hypothesis that leprosy was an infectious disease (27).

In the wake of cholera, and John Snow's convincing epidemiological research, the concept of infection as a cause of disease was boosted. But the concept was certainly not new, and already around 1840, Jacob Henle (1809-85), on a theoretical basis, had defined his postulates necessary to comply with before a microbe could be proven to cause a disease, postulates revised by Robert Koch in 1884. Technical improvements had provided better microscopes, and during the first six decades of the $19^{\text {th }}$ century a number of newly discovered microorganisms had been suggested to be the cause of various diseases (28). Still, when Hansen started his research, no bacillus had been shown to be the cause of any chronic disease. The first microorganism demonstrated to cause disease according to the postulates was the anthrax bacillus accounted for by Casimir Davaine (1812-82) in 1869 (28).

In his memoirs (29), Hansen also referred to great inspiration from Charles Darwin (1809-82) with respect to scientific method in general. In 1870 on a sabbatical tour in Europe, visiting a number of German medical laboratories, he was acquainted with "The Origin of Species" (in a German translation!), later considered by a rather atheistic Hansen as a replacement for the Bible.

More specifically, Hansen was influenced by a report from Dutch Guiana which in 1869 claimed that infection was the only cause of leprosy (30). The author observed leprosy in people who had migrated to high prevalent areas (Surinam) from areas without leprosy (The Netherlands) and with no sick relatives. In 1872 , one year before the discovery of the leprosy bacillus, Hansen wrote perhaps a little conceitedly that "in case someone might like to know, I can certainly state that it was Drognat Landre's book that made me understand that infectiousness was not paid sufficient attention to by us" (i.e. in Norway) (31).

In his first two papers published in 1869 and 1870, Hansen described the results of his clinical and pathological studies (32). He concluded that leprosy was a specific disease, representing a nosological entity with a specific etiology and not simply a degenerative condition resulting from various causes. In his 1870 paper, Hansen discussed the etiology of the disease. He pointed out that most of his findings indicated that leprosy was a "chronic infectious disease". It is not evident that this term had the same meaning as today. Still, it is quite clear that Hansen assumed that leprosy was communicated from person to person by some infectious matter, but he realized that he, so far, was unable to prove it. This was specifically stated in his 1872 paper (32) in which he gave an evaluation of the debate on etiology carried on in professional circles. His critical mind is reflected in a comment to $E$. Ferdinand Lochmann (1820-91) a professor of hygiene who had been an arduous contagionist in the debate on cholera. Lochman claimed that certain of Hansen's pathological findings proved that the disease was infectious (26). However, Hansen pointed out that this conclusion was unjustified. Besides, it is interesting to note that Hansen, a dedicated contagionist in leprosy, in this paper referred to tuberculosis as a hereditary disease.

Hansen's main treatise "Investigations on the causes of leprosy" (33) was published in 1874 with a shorter English version "On the etiology of leprosy" in 1875. 
Initially, Hansen compared the occurrence of leprosy in various areas based on data from the Leprosy Registry with total mortality in the same areas and found no association, indicating that poor living conditions were not the cause of leprosy. Next, some patients living in Bergen had no relatives with leprosy, but all of them had been in contact with leprosy patients. Thus, heredity had played no part in these cases and they seemed to be attributable to infection. This conclusion was supported by the results of comprehensive field studies carried out by Hansen in west Norway during the summers of 1871 and 1872. Next, Hansen presented results based on meticulous analyses of the Leprosy Registry indicating that isolation of patients in terms of hospitalization caused a decline in subsequent incidence. In analyses of a large number of health districts, an association was observed between the degree of hospitalization and the subsequent fall in incidence.

In Hansen's mind, all these results suggested that leprosy was an infectious disease transmitted by a microorganism and he was determined to find it. Examination of blood was unsuccessful. However, on 28 February 1873 (32), he found, in leprous nodules, "small staff like bodies, much resembling bacteria, lying within the cells" and added that they were consistent with the illustrations of bacteria earlier published by E. Klebs (1834-1913) (33). Still Hansen prudently concluded that "Though unable to discover any differences between these bodies and true bacteria, I will not venture to declare them to be actually identical".

In the history of medicine, Hansen has always been considered a pioneer in bacteriology referred to as the discoverer of the leprosy bacillus (25). However, there emerges also a picture of an eminent epidemiologist who realized the potentials of register based research and who also conducted comprehensive field epidemiological studies. In many ways, Hansen's elegant epidemiological analysis including his convincing results seemed to be the most important among his achievements. Still, it is interesting to note that the concept of register based research was not yet established. Hansen, as well as all subsequent authors publishing on leprosy in Norway, always referred to patient "numerations" and never to a register.

\section{CONTROVERSIES AND COMPLICATIONS}

Hansen's 1874 paper was a provocation to a most skeptical international medical establishment. Opponents held that the bacillus was just a saprophyte with no pathogenic effect. None of Henle's postulates was complied with. The bacterium could not be found in all patients, it could not be cultivated and it could not induce disease in laboratory animals. After a lot of unsuccessful attempts to stain the bacillus, Hansen welcomed in a collaborative spirit a young and aspiring German colleague visiting from Robert Koch's (1843-1910) laboratory in Breslau, Albert Neisser (1855-1916). Their joint efforts to stain the bacillus were also in vain, but after returning to Breslau, Neisser succeeded. He immediately published his results, claiming that he was the discoverer of the leprosy bacillus (34). Hansen reacted promptly publishing his claim of priority in Nordic, English, French and German scientific journals, however, followed by new claims from Neisser (34).

The Hansen-Neisser controversy had nationalistic implications. Hansen obtained broad support from his countrymen, lay as well as scientific. Even Danielssen, who until his death remained a doubter of Hansen's conclusions, found Neisser's behaviour unacceptable. Perhaps a bit priggish, Hansen concluded in his memoirs (29) that his 1880 paper in German (32) "effectively established the fact that it was I who found leprosy's origin. In medical literature it is now partly referred to as the Leprosy Bacillus, partly as Hansen's disease".

However, Hansen's uncertainty, widely shared by colleagues, with respect to the significance of his bacteriological findings, led to an ominous experiment. In his 1874 treatise, Hansen referred to a series of unsuccessful experiments in which he tried to comply with one of Henle's postulates, viz. to induce disease in animals after inoculation of infectious matter. After negative results in a number of different laboratory animals, Hansen felt that human experiments should be conducted. Before him, Danielssen had inoculated tissue from leprous nodules into himself, members of his medical staff and into patients with other diseases; all with negative results.

In consultation with Koch, Hansen decided to inoculate leprous tissue from a lepromatous patient into conjunctiva of a tuberculoid patient, representing the two polar types in leprosy. The intention was to produce lepromatous manifestation in a tuberculoid patient. In 1879, Hansen conducted this experiment in two patients also with negative results. However, one of these cases led, in 1880 , to a legal charge against Hansen who at that time had become Chief Medical Officer for Leprosy. Hansen was charged with undertaking "without the patient's consent and against her wishes an operation which apparently had not caused and possibly could not cause lasting damage to her eye, but had nevertheless occasioned her much anxiety and not inconsiderably pain" (35). Before the Ministry of Justice decided to proceed with the charge, opinions were sought from the Bergen City Medical Officer and the National Director of Public Health. Both strongly supported Hansen and the latter advised nothing further than "to administer a severe reprimand" (35). Still, Hansen was sentenced to forfeiture of his post at the hospital where the experiment had been conducted. Hansen never mentioned this incident in his memoirs.

At the centenary of the discovery of the leprosy bacillus, in 1973, justice of the Supreme Court of Norway, Knut Blom, gave a review of this sentence (35). Blom contended that in the legal perspective of that time and also in the context of contemporary law 
in Norway, Hansen was guilty as charged. He stressed the failure of Hansen to obtain informed consent and concluded that "there is no reason to assume that an operation of the sort undertaken by Hansen would infringe the law if consent was first obtained" (35). However, whether this statement is consistent with medical ethics is questionable; some experiments, of which Hansen's is one, should not be conducted even with an informed consent.

Also from a scientific point of view the experiment was questionable; a negative result, as obtained, would contradict a correct hypothesis and a positive result would have been of limited value as the patient already had leprosy. Later, Hansen continued his experiments with inoculation of infectious matter, but only in animals and all with negative results. Only in the 1970s, positive results of inoculation were obtained in the nine banded armadillo, one of few animals susceptible to leprosy.

\section{LEPROSY CONTROL AND LEGISLATION}

Even with all these negative results, Hansen succeeded in convincing lay as well as learned that leprosy was an infectious disease. Most likely, this was due to Hansen's epidemiological results obtained from the processing of the data in the Leprosy Registry. Thus, already in 1877 special legislation was enacted based on the understanding that leprosy was an infectious disease, namely the "Act of the Maintenance of Poor Lepers etc.". According to the law a system of social support from medieval time was discontinued for leprosy patients. By this system (legd) people were sent from farm to farm with stays of varying length, a system considered instrumental for the propagation of an infectious disease. Hereafter patients who could not care for themselves were hospitalized. In 1885 the legislation was considerably extended by the "Act on the Seclusion of Lepers etc." stating that all patients had to be either isolated in a separate room in their home or had to be hospitalized (32).

The act of 1877 was passed without much opposition. However, the bill proposed in 1885 was extensively debated in professional circles (16) even though it was claimed that the bill simply represented a legitimate recognition of a practice that had gradually evolved. Isolation was considered an intolerable burden to patients who were already so sorely tried, and it was claimed that the disease could be eradicated without the use of isolation. However, Hansen was once again able to demonstrate, on the basis of data from the Leprosy Registry, that the incidence of the disease had declined most rapidly in the districts in which hospitalization had been most strictly enforced.

\section{INTERNATIONAL RECOGNITION}

Already in 1873, Norway was visited by the British Surgeon Major H. V. Carter who was sent by the British Government from India to study Norwegian leprosy control. In his report, Carter recommended the introduction in India of parts of the Norwegian programme (16). In 1890, R. Roose published his book "Leprosy and its prevention as illustrated by Norwegian experience" in which he emphasized the importance of isolating the patients "to restrain the spread of leprosy by infection" (16).

Yet, the jewel in the crown was won in Berlin in 1897 at the first International Leprosy Congress. The congress passed the following resolution: "The system of compulsory notifycation, surveillance and isolation enforced in Norway is to be recommended in all nations with autonomous municipalities and a sufficient number of doctors" (16).

\section{CONCLUSIONS AND IMPLICATIONS}

The waves of freedom ensuing from the French revolution in terms of various reform movements also hit Norwegian shores. Consequences were observed in political as well as medical circles causing progress in epidemiological research and preventive medicine in various fields. However, international epoch making achievements were obtained in leprosy. The Norwegian triumphs in research on the epidemiology of leprosy and the triumphs of the ensuing control measures introduced in the fight against the disease were not only internationally recognized. The Norwegian control policy was recommended and eventually implemented in most countries in which leprosy occurred, even though often with a more radical isolation than the one practiced in Norway.

Even though the concept was not established or commented on at the time, nor during several decades, these triumphs originated in registry based research which eventually has become a hallmark of Norwegian epidemiology with groundbreaking achievements in tuberculosis, cancer and perinatal medicine. Today, it is most gratifying that the Research Council of Norway and the governmental committee for health science in the $21^{\text {st }}$ century state that register based research would represent a strategic international niche for future Norwegian epidemiology.

\section{REFERENCES}

1. Hilts VL. Epidemiology and the statistical movement. In: Lilienfeld AM, ed. Times, Places and Persons. Baltimore, MD: Johns Hopkins University Press, 1980: 43-55.

2. Lilienfeld DE, Lilienfeld AM. The French influence on the development of epidemiology. In: Lilienfeld AM, ed. Times, Places and Persons. Baltimore, MD: Johns Hopkins University Press, 1980: 28-38. 
3. Munthe P. Eilert Sundt. Norsk biografisk leksikon, 2nd edn. Oslo, 2005.

4. Sundt E. Om Dødeligheten i Norge. Christiania, 1855.

5. Irgens LM, Skjærven R, Lie RT. Secular trends of sudden infant death syndrome and other causes of post perinatal mortality in Norwegian birth cohorts 1967-84. Acta Paediatr Scand 1989; 78: 228-32.

6. Irgens LM, Skjærven R. Sudden infant death syndrome and post perinatal mortality in Norwegian birth cohorts 19678-1980. Acta Paediatr Scand 1986; 75: 523-9.

7. Carpenter RG, Irgens LM, Blair P, England PD, Fleming P,Huber J, Jorch G, Schreuder P. Sudden unexplained infant death in 20 regions in Europe: case control study. Lancet 2004; 363: 185-91.

8. Lund PJ. Semmelweis - en varsler. Tidsskr Nor Legefor 2006; 126: 1776-9.

9. Irgens LM, Bjerkedal T. Utvikling av informasjonssystemer i helsesektoren og bruken av disse i det forebyggende helsearbeid. Tidsskr Nor Lagefor 1976; 96: 295-300.

10. Torstvei L, Vesterhus P. Kolera og karantene i Kristiansand. Tidsskr Nor Legefor 2005; 125: 3490-3.

11. Moseng OG. Kolera og karantene. In: Moseng OG. Det offentlige helsevesen i Norge 1603-2003, vol. 1. Oslo: Universitetsforlaget, 2003: 283-313.

12. Irgens LM, Bjerkedal T. Epidemiology of leprosy in Norway: the history of the National Leprosy Registry of Norway from 1856 until today. Int J Epidemiol 1973; 2: 81-9.

13. Homan C, Hartwig CH. Om dysenteria-epidemien i Kragerøs lægedistrikt. Nor Mag Lagev 1860; 14: 217-70, 297-359.

14. Homan C, Hartwig CH. Meddelelse om nervefeberen i Kragerøs lægedistrikt aar 1864. Nor Mag Lagev 1865; 19: 433-501.

15. Thjøtta T. Lærebok i bakteriologi. Oslo: Fabritius, 1946.

16. Irgens LM. Leprosy in Norway: an interplay of research and public health work. Int J Leprosy 1973; 41: 18998.

17. Steen J. 1814. Oslo: Cappelen, 1989.

18. Helle KB. DC Danielssen, en kjempe for sin tid. Bergen: Fagbokforlaget, 2014.

19. Danielssen DC, Boeck CW. Traite de la Spedalskhed ou Elephanthiasis des Grecs. Paris, 1848.

20. Virchow R. Die Krankhaften Geschwülste. Berlin: A. Hirschwald, 1864-5, p. 503.

21. Steffens H. Bokanmeldelse. Norsk Tidsskrift for Videnskab og Litteratur 1848; 2: 187-97.

22. Diskusjon i Det medicinske Selskab angaaende den spedalske Sygdom. Nor Mag Lagev 1857; 11: 445-540, 605-84.

23. Beretning for 1856 fra Overlægen for den spedalske Sygdom til Departementet for det Indre. Christiania, 1857.

24. Irgens LM. Leprosy in Norway. An epidemiological study based on a national patient registry. Lepr Rev 1980; 51 (Suppl 1): 1-130.

25. Vogelsang TM. Gerhard Henrik Armauer Hansen. Oslo: Gyldendal, 1968.

26. Lochmann F. Om Spedalskheden. Christiania, 1871.

27. Beretning for 1857 fra Overlægen for den spedalske Sygdom til Departementet for det Indre. Christiania, 1858.

28. Shryock RH. Germ theories in medicine prior to 1870: Further comments to continuity in science. Clio Med 1972; 7: 81-109.

29. Armauer Hansen G. Livserindringer og betragtninger. Kristiania, 1910.

30. Menke HE, Faber WR, Pieters T. Charles Louis Drognat Landre and Gerhard Henrik Armauer Hansen; contribution from a Dutch colony to the discovery of the leprosy bacterium. Lepr Rev 2010; 81: 82-6.

31. Hansen GHA. Om vort Kjendskab til Spedalskhedens Aarsager og om vore Forholdsregler mod Sygdommen. Nor Mag Lagev 1872; 3: 1-37.

32. Irgens LM. The discovery of Mycobacterium leprae. A medical achievement in the light of evolving scientific methods. Am J Dermatopathol 1984; 6: 337-43.

33. Hansen GHA. Undersøgelser angaaende Spedalskhedens Aarsager. Nor Mag Laegev 1874; 3: 1-88.

34. Fite GL, Wade HW. The contribution of Neisser to the establishment of the Hansen bacillus as the etiological agent of leprosy and the socalled Hansen - Neisser controversy. Int J Leprosy 1955; 23: 418-28.

35. Blom K. Armauer Hansen and his human leprosy transmission. Medical ethics and legal rights. Int J Leprosy 1973; 41: 199-207. 